\title{
Transcriptomic study of 39 ostreid herpesvirus 1 genes during an experimental infection
}

\author{
Amélie Segarra $^{\mathrm{a}}$, Nicole Faury ${ }^{\mathrm{a}}$, Jean-François Pépin ${ }^{\mathrm{b}}$, Tristan Renault ${ }^{\mathrm{a}, \text { * }}$
}

\begin{abstract}
${ }^{a}$ Ifremer (Institut Français de Recherche pour l'Exploitation de la Mer), Unité Santé, Génétique et Microbiologie des Mollusques (SG2M), Laboratoire de Génétique et Pathologie des Mollusques Marins (LGPMM), Avenue de Mus de Loup, 17390 La Tremblade, France

${ }^{\mathrm{b}}$ Ifremer, Laboratoire Environnement Ressources des Pertuis Charentais (LERPC), Avenue de Mus de Loup, 17390 La Tremblade, France
\end{abstract}

*: Corresponding author : Tristant Renault, tel.: +33 546762626 ; fax: +33546762611; email address : Tristan.Renault@ifremer.fr

\begin{abstract}
:
Massive mortality outbreaks have been reported in France since 2008 among Pacific oysters, Crassostrea gigas, with the detection of a particular OsHV-1 variant called $\mu$ Var. Virus infection can be induced in healthy spat in experimental conditions allowing to better understand the disease process, including viral gene expression.
\end{abstract}

Although gene expression of other herpesviruses has been widely studied, we provide the first study following viral gene expression of OsHV-1 over time. In this context, an in vivo transcriptomic study targeting 39 OsHV-1 genes was carried out during an experimental infection of Pacific oyster spat. For the first time, several OsHV-1 mRNAs were detected by real-time PCR at $0 \mathrm{~h}, 2 \mathrm{~h}, 4 \mathrm{~h}, 18 \mathrm{~h}, 26 \mathrm{~h}$ and $42 \mathrm{~h}$ post injection. Several transcripts were detected at $2 \mathrm{~h}$ post infection and at $18 \mathrm{~h}$ post infection for all selected ORFs. Quantification of virus gene expression at different times of infection was also carried out using an oyster housekeeping gene, Elongation factor.

Developing an OsHV-1-specific reverse transcriptase real time PCR targeting 39 viral gene appears a new tool in terms of diagnosis and can be used to complement viral DNA detection in order to monitor viral replication. 


\section{Graphical abstract}

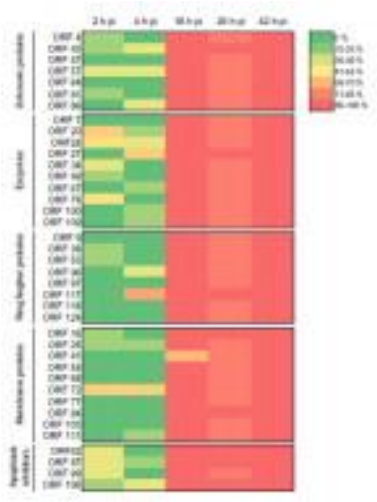

\section{Highlights}

- We studied the detection and expression kinetics of 39 OsHV-1 genes. Viral RNA detection would allow much better understanding on the viral cycle. OsHV-1 mRNAs were detected during the early hours of infection, 2 and $4 \mathrm{hpi}$. Viral mRNAs were all detected at 18 hours post infection.

Keywords : Crassostrea gigas ; OsHV-1 ; Viral gene expression ; Inhibitors of Apoptosis ; Real time PCR ; Elongation Factor 


\section{Introduction}

Herpesviruses are widely distributed among vertebrates and have been also reported in invertebrates. A herpesvirus, called ostreid herpesvirus 1 (OsHV-1), has been identified in different bivalve species causing massive mortality outbreaks especially in Pacific oyster, Crassostrea gigas, larvae and spat (Garcia et al., 2011; Segarra et al., 2010; Arzul et al., 2001 ;(Renault et al., 1994; Arzul et al., 2001; Segarra et al., 2010; Garcia et al., 2011). In this context, tools have been developed such as immunohistochemistry (Le Deuff et al., 1995), in situ hybridization ( Lipart and Renault, 2002; Renault and Lipart, 1998), polymerase chain reaction ( Renault et al., 2000; Renault and Lipart, 1998) and quantitative polymerase chain reaction (Pepin et al., 2008) in order to detect OsHV-1. The virus genome was completely sequenced (GenBank accession number AY509253) and encodes at least 124 genes (Davison et al., 2005). However, more than $70 \%$ genes encode putative proteins presenting no homology with proteins from databases (Davison et al., 2005).

Many in vitro studies have been performed in order to define virus gene transcription for several mammalian herpesviruses using chemicals including cyclohemixide, as inhibitors of gene expression (Rubins et al., 2008; Honess and Roizman, 1975, 1974). Currently, no bivalve cell lines are available and no in vitro studies of OsHV-1 gene expression can be performed. Despite these constraints, 2 studies reported OsHV-1 gene expression targeting a single virus gene, ORF4 (protein of unknown function) (Renault et al., 2011) or ORF 100 (DNA polymerase) (Burge and Friedman 2012). 
Recently, techniques including reverse transcription real time PCR, microarray or RNAseq have been used to study virus gene expression (Beurden et al., 2013; Rossetto et al., 2013; Tombácz et al., 2009; Rubins et al., 2008). In view of the low number of genes encoded by the virus, we selected the RT-qPCR technique to confirm OsHV-1 mRNA presence. For the first time, 39 OsHV-1 mRNAs were studied and detected in Pacific oyster spat during an experimental infection (0, 2, 4, 18, 26, and 42 hours post injection). Relative expression was also performed on viral genes detected at all times. Thus, 8 viral genes were analysed using a host housekeeping gene. For this purpose, the stability of four commonly used housekeeping genes in real time quantitative gene expression studies was first determined in C. gigas spat challenged by OsHV-1. 


\section{Material and methods}

\subsection{Animals}

A pool of Pacific oysters Crassostrea gigas 7 month old was used in the present study. Oysters were produced in March 2011 at Ifremer facilities in La Tremblade (Charente Maritime, France) during the course of the Bivalife EU funded project (FP7, n² 266157, 2011-2014).

\subsection{Defining mortality kinetics in experimentally infected Pacific oysters}

Forty oysters were "anaesthetized" during $4 \mathrm{~h}$ in a solution containing magnesium chloride ( $\mathrm{MgCl} 2,50 \mathrm{~g} / \mathrm{L})$ in seawater (1 v)/ distilled water (4 v) (Namba et al., 1995). In order to perform a maximum of sampling the first day post infection and before mortality, several dilutions of a viral suspension at $1.5 .10^{6}$ copies of viral $\mathrm{DNA} / \mu \mathrm{L}$ were tested: $1.5 .10^{6}, 5.10^{4}(1 / 25)$ or $1.2 .10^{3}(1 / 125)$ copies of viral DNA/ $\mu \mathrm{L}$. Based on mortality records (data not shown), $100 \mu \mathrm{L}$ of a OsHV-1 ( $\mu$ Var genotype, (Segarra et al., 2010)) suspension at $1.2 .10^{3}$ copies of viral $\mathrm{DNA} / \mu \mathrm{L}$ were injected into the adductor muscle. Then, of 20 oysters using a $1 \mathrm{~mL}$ syringe (Schikorski et al., 2011) and placed in a tank with $5 \mathrm{~L}$ of filtered seawater $(1 \mu \mathrm{m})$ at $22{ }^{\circ} \mathrm{C}$. The bacterial content of the viral suspension was tested before each challenge by plating on Marine agar. A negative control consisted of 20 oysters intra-muscularly injected with $100 \mu \mathrm{L}$ of sterile artificial seawater and placed in another tank.

Mortality was monitored during 90 hours after injection and percentages of cumulative mortality were daily defined for both conditions (oysters infected with 
OsHV-1 or injected with sterile artificial seawater). Dead oysters were removed from tanks during the time course of the experiment. The experiment was performed successively 3 times.

\subsection{Studying housekeeping genes and virus gene expression in OsHV- 1 experimentally infected Pacific oysters: experimental design}

One hundred and twenty oysters were first "anesthetized" during $4 \mathrm{~h}$ as previously described. One hundred $\mu \mathrm{L}$ of viral suspension were injected into the adductor muscle of 60 oysters. A negative control consisted of 60 oysters intra-muscularly injected with $100 \mu \mathrm{L}$ of sterile artificial seawater. Sixty negative control oysters were then randomly distributed in 3 tanks and 60 experimentally infected oysters placed in 3 other tanks supplied with $5 \mathrm{~L}$ of filtered seawater $(1 \mu \mathrm{m})$ at $22^{\circ} \mathrm{C}$.

Several sampling times were determined based on previously defined mortality kinetics after experimental virus infection. The sampling points were $0 \mathrm{~h}, 2 \mathrm{~h}, 4 \mathrm{~h}, 18$ $\mathrm{h}$ and $26 \mathrm{~h}$ post injection before mortality occurred and at $42 \mathrm{~h}$ post injection during mortality outbreak. At each time and for each condition, 3 oysters were collected in each tank (9 individuals per time/condition) and 2 pieces of mantle were sampled from each individual. A piece of mantle (50 to 100mg) was disposed in a tube containing $1 \mathrm{~mL}$ of TRIZOL® Reagent ${ }^{\mathrm{TM}}$ (Ambion®) and frozen at $-80{ }^{\circ} \mathrm{C}$ for further RNA extraction. Another piece of mantle was directly frozen at $-20{ }^{\circ} \mathrm{C}$ for further total DNA extraction. Mantle was selected in the present study for real time RT PCR analysis as this organ has already been showed as a site of interest for viral DNA detection (Schikorski et al., 2011; Sauvage et al., 2009; Arzul et al., 2002).

\subsection{DNA extraction}


Total DNA extraction was performed from a mantle fragment from each collected sample. The DNA extraction was performed with QiAamp tissue mini kit $\circledast$ (QIAgen) according to the manufacturer's protocol. Elution was performed in $100 \mu \mathrm{L}$ of buffer AE provided in the kit.

\subsection{Total RNA extraction and cDNA synthesis}

Total RNA was extracted using TRIZOL ${ }^{\circledR}$ Reagent ${ }^{\mathrm{TM}}$ (Ambion ${ }^{\circledR}$ ) according to the manufacturer's recommendation. Total RNA was treated with Turbo ${ }^{\mathrm{TM}}$ DNAse (Ambion ${ }^{\circledR}$ ) to remove genomic DNA. The RNA quality and quantity were determined using NanoDrop 2000 (Thermo Scientific) and Bioanalyser 2100 (Agilent). Firststrand cDNA synthesis was carried out using the SuperScript $\AA$ III First-Strand Synthesis System (Invitrogen) using $8000 \mathrm{ng}$ of RNA treated. A No RT was performed after each DNAse treatment using real time PCR in order to control absence of oyster and/or virus genomic DNA.

\subsection{Real time PCRs and relative expression}

Real time quantitative PCR was performed in duplicate using a M×3000 Thermocycler sequence detector (Agilent). All forward and reverse primers used in the present study were designed using primer3 software (Koressaar and Remm, 2007; Untergasser et al., 2012) and synthesised by Eurogentec. Using the same biological material the detection and quantification of OsHV-1 DNA was first carried out using a previously published real time PCR protocol (Pepin et al., 2008). In a second step, real time quantitative RT PCR was used in order (i) to select and validate a suited oyster housekeeping gene from Crassostrea gigas spat during OsHV-1 experimental infection and (ii) to study viral gene expression. Amplification 
reactions were performed in a total volume of $20 \mu \mathrm{L}$ to study oyster housekeeping genes and viral gene expression. Each well contained $5 \mu \mathrm{L}$ of cDNA dilution (1/30), $10 \mu \mathrm{L}$ of Brillant ${ }^{\circ}$ SYBR® Green III PCR Master Mix (Agilent), $2 \mu \mathrm{L}$ of each primer (3 $\mu \mathrm{M})$ and $1 \mu \mathrm{L}$ of distilled water. Real time PCR cycling conditions were as follow: 3 $\min$ at $95^{\circ} \mathrm{C}$, followed by 40 cycles of amplification at $95^{\circ} \mathrm{C}$ for $5 \mathrm{~s}, 60^{\circ} \mathrm{C}$ for $20 \mathrm{~s}$. Melting curves were also plotted $\left(55-95^{\circ} \mathrm{C}\right)$ in order to ensure that a single PCR product was amplified for each set of primers. In all cases negative controls (without cDNA) were included to rule out DNA contamination.

Concerning selection of a suited oyster housekeeping gene, the expressed sequence tags (EST) of 4 candidate genes were obtained from a subtracted cDNA library of $C$. gigas and four primer pairs were designed (Table 1). Individual samples of infected or non-infected oyster spat were collected and analysed at 0 h, 2 h, 4 h, 18 h, 26 h and $42 \mathrm{~h}$ post infection.

To study virus gene expression, 39 genes were selected based on protein functions or structures of related proteins among the 124 ORFs of OsHV-1 (Davison et al., 2005) and belongs to 5 groups/families of genes (Figure 1). (i) The first group consisted of 7 ORFs encode unknown proteins (ORF 4, ORF43, ORF47, ORF 57, ORF64, ORF81 and ORF 86) whose 2 ORFs already used to differentiate virus specimens (Renault et al., 2012; Segarra et al., 2010), (ii) 10 genes encoding enzymes or proteins presenting known viral domains (ORF 7, ORF 20, ORF 24, ORF 27, ORF 34, ORF 49, ORF 67, ORF 75, ORF 100 and ORF 109), (iii) one family of Ring-finger genes with 8 members (ORF 9, ORF 38, ORF 53, ORF 96, ORF 97, ORF117, ORF 118, ORF 124), (iv) one family of genes predicted to encode membrane proteins (with 10 members: ORF 16, ORF 25, ORF 41, ORF 54, ORF 68, ORF 72, ORF 77, ORF 84, ORF 103 and ORF 111), (v) one family whose products 
were related to inhibitors of apoptosis (four members containing BIR domains: ORF 42, ORF 87, ORF 99, ORF 106) (Table 2). Thirty-nine specific primer pairs were designed on a unique gene sense or antisense and validated by real time PCR (Table 2). Standard curves were performed for each primer pair using serial dilutions of total DNA and PCR efficacy $\left(E=10^{(-1 / \text { slope })}\right)$ was calculated thanks to these curves (Rasmussen, 2001). Relative expression was performed using ORFs detected at all times. Thus, 8 viral ORFs were normalized using the selected oyster housekeeping gene of Crassostrea gigas, EF (GenBank, Accession No. AB122066) identified as the most stable one in the present study. Infected individuals collected at $2 \mathrm{~h}$ postinfection were used as calibrators. The relative quantification value (ratio R) was calculated using the method described by Pfaffl, 2001: $R=\left[\left(E_{\text {target }}\right)^{\Delta C T \text { target(control-sample })}\right] /$ $\left[\left(E_{E F \alpha-1}\right)^{\Delta C T} \quad E F \alpha-1\right.$ (control-sample) $]$. All amplification obtained by real time PCR was validated by sequencing using the PRISM® 3130 XL-Avant Genetic Analyzer with a $36 \mathrm{~cm}$ capillary array and POP 7 polymer (data not shown).

\subsection{Data analysis}

CTs were calculated with the Stratagene Mxpro software 4.0. To determine the expression stability of housekeeping gene candidates 2 excel applets were used, Genorm (Vandesompele et al., 2002) and Normfinder (Andersen et al., 2004). These programs calculate the gene expression normalization factor and determine the most stable internal controls. Genorm algorithm assumed that expression variation of the ratio of two ideal reference genes is identical in all samples. Based on pairwise variation of reference candidate genes, the stability measure ( $\mathrm{M}$ value), which reflects instability in expression levels of one gene, is calculated. $M$ values $<1.5$ are considered as stable reference genes. The main goal of the Normfinder program is to determine the expression stability of candidate references for all samples according 
to their intra- and inter-group variation. NormFinder provides a direct measure for expression variation of each gene under a given set of experimental conditions. Based on this algorithm, genes with the lowest average expression stability values will be top ranked.

Results for relative expression for the 8 selected ORFs were expressed as mean \pm standard error. A Mann-Whitney test was used to analyze OsHV-1 gene expressions between each time. Correlations between the viral DNA detection and the viral transcript detection were tested with the Spearman's nonparametric rho (Rs) using XLSTAT software (version 2013). 


\section{Results}

Pacific oysters injected with the OsHV-1 suspension demonstrated high mortality rates in the 3 experiments (Figure 2), whereas oysters injected with sterile artificial seawater showed no mortality (Figure 2). The cumulative mortality rate reached $10.5 \%$ at 42 hours post injection, $40.8 \%$ after 66 hours and $63 \%$ at the end of the experiments (90 hours). Virus DNA quantification was performed for each individual collected during one experiment. No virus DNA was detected in control oysters. The first detection of virus DNA was observed 2 hours post injection. Individual OsHV-1 DNA amounts ranged from 0 to $7.5,0$ to $5 \times 10^{1}, 2.3 \times 10^{3}$ to $2.1 \times 10^{5}, 1.7 \times 10^{1}$ to 1 $\times 10^{6}$ and $1 \times 10^{3}$ to $1.2 \times 10^{6}$ DNA copies per $n g$ of total DNA at $2 \mathrm{~h}, 4 \mathrm{~h}, 18 \mathrm{~h}, 26 \mathrm{~h}$ and $42 \mathrm{~h}$ pi respectively (Figure 3 ).

The relative expression level of 4 oyster genes was studied over mantle tissue during the experimental infection of Pacific oyster, Crassostrea gigas, by OsHV-1. Thus, the most popular tools of Genorm and Normfinder were used to aid the selection of suitable reference gene from among the candidates. Those two programs evaluate gene expression stability using different algorithms and consider genes with low expression stability values to be more stably expressed than those with high values. According $\mathrm{M}$ values, ranking from the least to the most stable one out of the 4 genes was as follows: Actin ( $M=0.87)$, GAPDH $(M=0.71), L 5(M=0.6)$ and $E F(M=0.6)$ with Genorm (data not shown). Stability index were follows: Actin (0.63), GAPDH (0.4), L5 (0.38) and EF (0.29) with Normfinder (data not shown). Thus, the most stable gene reported was EF with the lowest value from both softwares. 
Based on protein functions, structures and on families genes described by Davison et al. (2005), 39 ORFs belonging to 5 groups/families of genes were selected in this study (Figure 1). Although viral transcripts of some OsHV-1 ORFs were detected by real time RT PCR in few individuals as soon as $2 \mathrm{~h}$ and $4 \mathrm{~h}$ pi at low quantities, viral transcripts were mainly quantifiable from $18 \mathrm{~h}$ pi. More precisely, 18 viral transcripts were detected in few individuals at 2 h (ORF 4, ORF 16, ORF 20, ORF 24, ORF 25, ORF 34, ORF 38, ORF 42, ORF 43, ORF 49, ORF 53, ORF 57, ORF 72, ORF 75, ORF 81, ORF 87, ORF 99 and ORF 106) and 16 ORFs at 4h (ORF 20, ORF 24, ORF 25, ORF 27 , ORF 43 , ORF 57 , ORF 67 , ORF 72 , ORF 86 , ORF 87 , ORF 96 , ORF 100, ORF 106, ORF 109, ORF 111 and ORF 117) in all groups (Figure 4). Moreover, the DNA viral quantity was correlated with each viral transcript during the experimental infection $(R s=0.81, \pm 0.1, p<0.0001)$.

Only the apoptosis inhibitor group (BIR with four members: ORF 42, ORF 87, ORF 99 and ORF 106) has all genes detected $2 \mathrm{~h}$ pi in a few of individuals (Figure 5).

A relative expression analysis was performed for ORFs detected at each time of collection. Thus, 8 virus genes were selected. They belong to 4 groups/families: (i) unknown proteins with ORF 43 and ORF 57, (ii) enzyme group with ORF 20 and ORF 24, (iii) menbrane protein group with ORF 25 and ORF 72 and, (iv) apoptosis inhibitors with ORF 87 and ORF 106 (Figure 6). No ORFs belonging to ring finger protein groups were detected at all times. Eight genes presented a relative expression significantly different between $4 \mathrm{~h}$ pi and $18 \mathrm{~h}$ pi $(\mathrm{p}=0.05)$. At $4 \mathrm{~h}$ pi, ORF 24 and ORF 25 were down regulated compared at $2 \mathrm{~h}$ pi. After this time, all ORFs were up regulated, especially ORF 87 . However, the expression level between 18, 26 and $42 \mathrm{~h}$ pi were variable. ORF 72 was more expressed at $18 \mathrm{~h}$ pi compared at 26 and $42 \mathrm{~h}$ pi. Nevertheless, the relative expressions of these 8 ORFs were not significantly different between 18,26 and $42 \mathrm{~h}$ pi. 


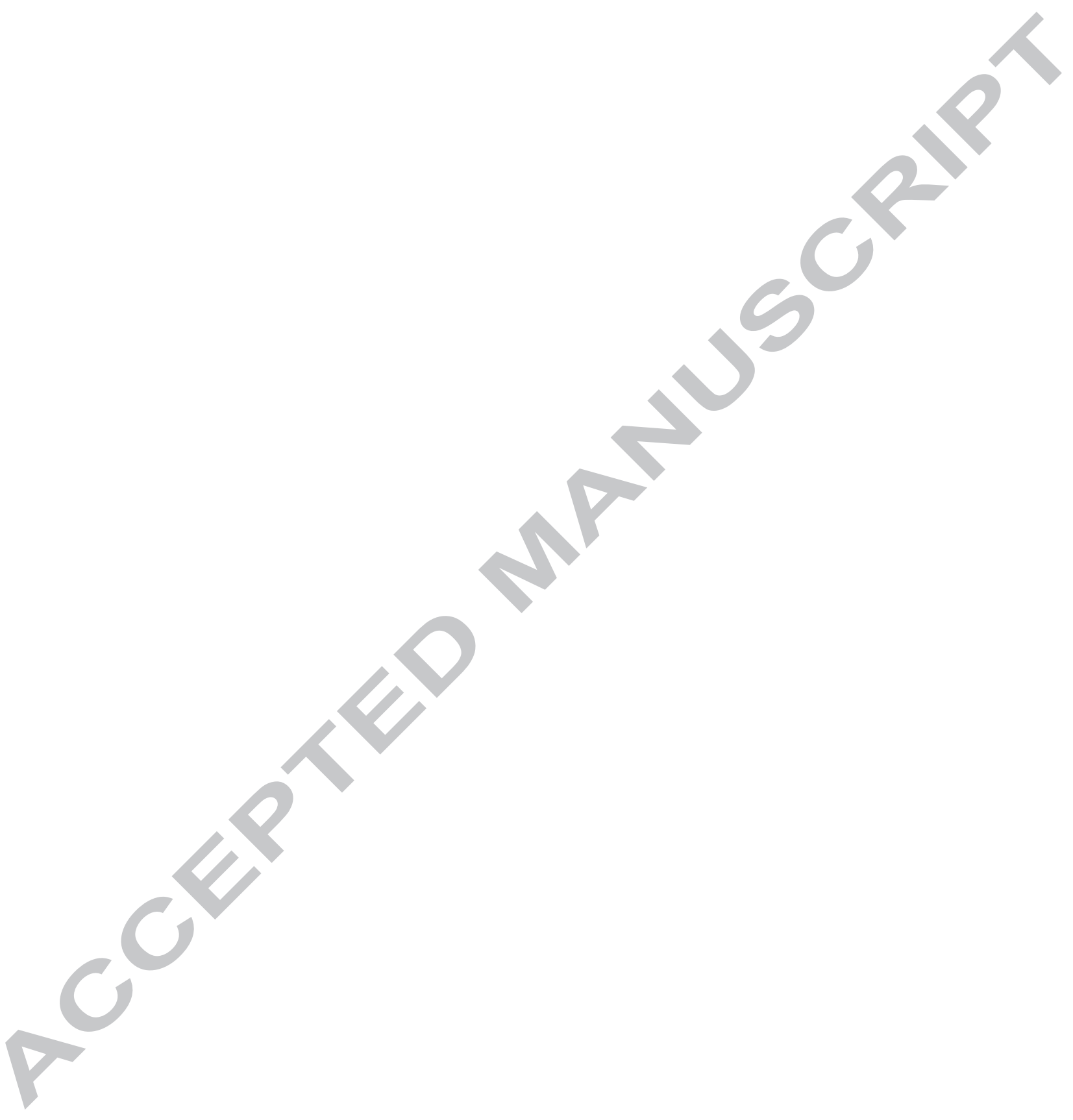




\section{Discussion}

High mortality rates and viral DNA detection in Pacific oyster spat after intramuscular injection confirmed active virus replication in experimentally infected animals as previously reported (Schikorski et al., 2011). In the present study we selected injection protocol rather than cohabitation in order to contaminate all animals at the same time. To study viral gene expression, animals were mainly collected before mortality occurred in order to detect viral transcripts as early as possible and to avoid degradation of such transcripts in dead or dying individuals.

Our study is the first to demonstrate OsHV-1 RNA detection early after exposure. Main differences in terms of RNA detection between virus genes were observed at 2 and $4 \mathrm{~h}$ pi. Moreover, virus transcripts were detected from $18 \mathrm{~h}$ pi for the 39 genes monitored in this study. This result was correlated with virus DNA quantity detected by real time PCR with high amounts detected from $18 \mathrm{~h} \mathrm{pi.}$

A few of studies were previously reported on OsHV-1 gene expression. The first detection of viral RNA was reported for the ORF 4 (unknown protein) in juveniles and adult oysters $48 \mathrm{~h}$ post-infection (Renault et al., 2011). Another study was performed based on ORF 100 (viral DNA polymerase) transcripts (Burge and Friedman, 2012). Burge and Friedman (2012) detected viral mRNA on day 1 and showed that DNA polymerase expression increased during the early days of infection in Crassostrea gigas larvae. Here, ORF 100 transcripts were detected at $18 \mathrm{~h}$ post-infection in oyster spat. DNA polymerase is essential for the replication of viral genomes during herpesvirus infections. Previous studies of the transcript of HSV-1 DNA polymerase gene (UL30) have classified it as a E gene (early gene) (Wobbe et al., 1993; Yager and Coen, 1988). Recently, Beurden et al. (2013) studied the genome-wide gene 
expression of anguillid herpesvirus 1 and reported that DNA polymerase (ORF 55) was also classed as an early gene. Apoptosis inhibitor genes (ORF 42, ORF 87, ORF 99 and ORF 106) were also detected as early as a $2 \mathrm{~h}$ post infection in a few of individuals. Typically, apoptosis inhibitors contain one or more BIR domains and often a carboxy-terminal Ring finger. Ring finger proteins have been shown to play a key role in transregulatory functions in vertebrate herpesviruses (Cohen and Nguyen, 1998; Moriuchi et al., 1994). The Ring finger domain of ICP0 and homologs from alphaherpesviruses are required for the activation of quiescent genomes blocking silencing of viral DNA (Everett et al., 2010; Gu and Roizman, 2009). Ince et al. (2008) showed that CIV Apoptosis inhibitor should be classified as an immediate-early CIV gene.

A major concern regarding viral gene expression is the choice of an internal reference gene control. Several studies on viral gene expression used a host gene as an internal control (Tombácz et al., 2009; Liu and Yang, 2005). The four selected housekeeping genes are involved in ribosomal metabolism (L5), cytoskeleton structure (Actin), protein metabolism (GAPDH) and elongation factor (EF), respectively. These genes are frequently used as housekeeping genes in mollusks (Du et al., 2013; Morga et al., 2010; Siah et al., 2008). Both algorithms gave EF gene as the most stable housekeeping gene when Crassostrea gigas spat were challenged by OsHV-1. EF1 was among the most frequently used housekeeping genes in several marine species (Morga et al., 2010; Araya et al., 2008). However, other housekeeping genes of interest have been also identified in C. gigas depending of experimental designs (Du et al., 2013; Green and Montagnani, 2013). The validation of EF as housekeeping gene allowed the study of viral expression genes by the relative expression method. The 8 ORFs detected at each time were selected 
and their relative expression was not significantly different between 18, 26 and $42 \mathrm{~h}$ pi, this result could be explained by a rapid cycle of replication of OsHV-1. As other herpesviruses, OsHV-1 could be able to replicate in less than 24 hours (Reichelt et al., 2009; Smith and Harven, 1973). ORF 87 (belonging to Apoptosis inhibitor group) was especially up regulated after $4 \mathrm{~h}$ pi. This result suggests an important role of IAPs in virus replication and disease development. IAPs may help the virus to limit the cellular apoptotic response.

Currently, it was not possible to affiliate the 39 OsHV-1 ORFs according to categories (immediate early, early or late genes) as described widely in vertebrate herpesvirus. Nevertheless, this study also demonstrates that OsHV-1 is able to replicate at $2 \mathrm{~h}$ pi in oyster spat based on RNA and DNA detection.

Finally, detection of a few of virus mRNAs before $18 \mathrm{~h}$ post-injection may also suggest a limit of the use of the real time RT PCR technique. As this technique targeted a particular gene, it is important to mention that the number of copies for a particular transcript could be lower than the number of copies of viral DNA in an animal at a particular collection time. Moreover, no precise information is available at a cellular level concerning viral replication sites. Mantle was selected in the present study for real time RT PCR analysis as it has already been showed as a site of viral DNA detection (Schikorski et al., 2011; Sauvage et al., 2009; Arzul et al., 2002). However, some differences in terms of genes expression could exist depending of targeted tissues or cells. Finally, similarly to virus DNA detection, an inter-individual variability of viral gene expression was observed between oysters for a same time point. Such differences could be partly explained by susceptibility differences between individuals. The use of bi-parental oysters as a source of infected material 
could be more appropriate to study the expression of OsHV-1 genes in C. gigas. An approach is in progress in the laboratory.

\section{Conclusions}

We studied the detection and expression kinetics of 39 OsHV-1 genes by real-time PCR at $0 \mathrm{~h}, 2 \mathrm{~h}, 4 \mathrm{~h}, 18 \mathrm{~h}, 26 \mathrm{~h}$ and $42 \mathrm{~h}$ post infection. For the first time, OsHV -1 mRNAs were detected during the early hours of infection and more precisely at 2, 4 and $18 \mathrm{~h}$ pi. Viral RNA detection by real-time PCR could be an additional tool in order to acquire a better understanding on the viral cycle, viral gene expression and spread of the virus. Although the results reported in the present study suggest that some OsHV-1 genes are expressed at $2 \mathrm{~h}$ further studies are needed to complete these first results. 


\section{Acknowledgement}

The authors wish to thank the Ifremer laboratory team in La Tremblade for the production of Pacific oysters and more precisely to L. Degrémont, D. Tourbiez and P. Haffner. We also want to thank A. Travers for the helpful input in her review of this paper. This work was supported by the EU funded project Bivalife (PF7, n²66157), the project MOLTRAQ (ERA NET EMIDA) and the Region Poitou-Charentes. 
Andersen, C.L., Jensen, J.L., Ørntoft, T.F., 2004. Normalization of Real-Time Quantitative Reverse Transcription-PCR Data: A Model-Based Variance Estimation Approach to Identify Genes Suited for Normalization, Applied to Bladder and Colon Cancer Data Sets. Cancer Res. 64, 5245-5250.

Araya, M.T., Siah, A., Mateo, D., Markham, F., McKenna, P., Johnson, G., Berthe, F.C.J., 2008. Selection and evaluation of housekeeping genes for haemocytes of soft-shell clams (Mya arenaria) challenged with Vibrio splendidus. J. Invertebr. Pathol. 99, 326-331.

Arzul, I., Renault, T., Lipart, C., 2001. Experimental herpes-like viral infections in marine bivalves: demonstration of interspecies transmission. Dis. Aquat. Organ. 46, 1-6.

Arzul, I., Renault, T., ThÃ@bault, A., GÃ@rard, A., 2002. Detection of oyster herpesvirus DNA and proteins in asymptomatic Crassostrea gigas adults. Virus Res. 84, 151-160.

Beurden, S.J., Peeters, B.P., Rottier, P.J., Davison, A.J., Engelsma, M.Y., 2013. Genome-wide gene expression analysis of anguillid herpesvirus 1. BMC Genomics 14, 83.

Burge, C.A., Friedman, C.S., 2012. Quantifying Ostreid Herpesvirus (OsHV-1) Genome Copies and Expression during Transmission. Microb. Ecol. 63, 596-604.

Cohen, J.I., Nguyen, H., 1998. Varicella-zoster virus ORF61 deletion mutants replicate in cell culture, but a mutant with stop codons in ORF61 reverts to wild-type virus. Virology 246, 306-316.

Davison, A.J., Trus, B.L., Cheng, N., Steven, A.C., Watson, M.S., Cunningham, C., Le Deuff, R.-M., Renault, T., 2005. A novel class of herpesvirus with bivalve hosts. J. Gen. Virol. 86, 41-53.

Du, Y., Zhang, L., Xu, F., Huang, B., Zhang, G., Li, L., 2013. Validation of housekeeping genes as internal controls for studying gene expression during Pacific oyster (Crassostrea gigas) development by quantitative real-time PCR. Fish Shellfish Immunol. 34, 939-945.

Everett, R.D., Boutell, C., McNair, C., Grant, L., Orr, A., 2010. Comparison of the Biological and Biochemical Activities of Several Members of the Alphaherpesvirus ICPO Family of Proteins. J. Virol. 84, 3476-3487.

Garcia, C., Thébault, A., Dégremont, L., Arzul, I., Miossec, L., Robert, M., Chollet, B., François, C., Joly, J.-P., Ferrand, S., Kerdudou, N., Renault, T., 2011. Ostreid herpesvirus 1 detection and relationship with Crassostrea gigas spat mortality in France between 1998 and 2006. Vet. Res. 42, 73.

Green, T.J., Montagnani, C., 2013. Poly 1:C induces a protective antiviral immune response in the Pacific oyster (Crassostrea gigas) against subsequent challenge with Ostreid herpesvirus (OsHV-1 $\mu$ var). Fish Shellfish Immunol. 35, 382-388.

Gu, H., Roizman, B., 2009. The Two Functions of Herpes Simplex Virus 1 ICPO, Inhibition of Silencing by the CoREST/REST/HDAC Complex and Degradation of PML, Are Executed in Tandem. J. Virol. 83, 181-187.

Honess, R.W., Roizman, B., 1974. Regulation of Herpesvirus Macromolecular Synthesis I. Cascade Regulation of the Synthesis of Three Groups of Viral Proteins 1. J. Virol. 14, 8-19.

Honess, R.W., Roizman, B., 1975. Regulation of herpesvirus macromolecular synthesis: sequential transition of polypeptide synthesis requires functional viral polypeptides. Proc. Natl. Acad. Sci. U. S. A. 72, 1276-1280.

Koressaar, T., Remm, M., 2007. Enhancements and modifications of primer design program Primer3. Bioinformatics 23, 1289-1291.

Le Deuff, R.M., Renault, T., Cochennec, N., 1995. Antibodies specific for channel catfish virus crossreact with Pacific oyster, Crassostrea gigas, herpes-like virus. Vet. Res. 26, 526-529.

Lipart, C., Renault, T., 2002. Herpes-like virus detection in infected Crassostrea gigas spat using DIGlabelled probes. J. Virol. Methods 101, 1-10.

Liu, X., Yang, F., 2005. Identification and function of a shrimp white spot syndrome virus (WSSV) gene that encodes a dUTPase. Virus Res. 110, 21-30.

Morga, B., Arzul, I., Faury, N., Renault, T., 2010. Identification of genes from flat oyster Ostrea edulis as suitable housekeeping genes for quantitative real time PCR. Fish Shellfish Immunol. 29, 937-945. 
Moriuchi, H., Moriuchi, M., Cohen, J.I., 1994. The RING Finger Domain of the Varicella-Zoster Virus Open Reading Frame 61 Protein Is Required for Its Transregulatory Functions. Virology 205, 238-246.

Namba, K., Kobayashi, M., Aida, S., Uematsu, K., Yoshida, M., Kondo, Y., Miyata, Y., 1995. Persistent relaxation of the adductor muscle of oyster Crassostrea gigas induced by magnesium ion. Fish. Sci. v. 61(2) p. 241-244.

Pepin, J.F., Riou, A., Renault, T., 2008. Rapid and sensitive detection of ostreid herpesvirus 1 in oyster samples by real-time PCR. J. Virol. Methods 149, 269-276.

Pfaffl, M.W., 2001. A new mathematical model for relative quantification in real-time RT-PCR. Nucleic Acids Res. 29, e45.

Reichelt, M., Brady, J., Arvin, A.M., 2009. The Replication Cycle of Varicella-Zoster Virus: Analysis of the Kinetics of Viral Protein Expression, Genome Synthesis, and Virion Assembly at the Single-Cell Level. J. Virol. 83, 3904-3918.

Renault, T., Cochennec, N., Le Deuff, R.-M., Chollet, B., 1994. Herpes-like virus infecting Japanese oyster (Crassostrea gigas) spat. Bull. Eur. Assoc. Fish Pathol. 14, 64-66.

Renault, T., Faury, N., Barbosa-Solomieu, V., Moreau, K., 2011. Suppression substractive hybridisation (SSH) and real time PCR reveal differential gene expression in the Pacific cupped oyster, Crassostrea gigas, challenged with Ostreid herpesvirus 1. Dev. Comp. Immunol. 35, 725-735.

Renault, T., Le Deuff, R.-M., Lipart, C., Delsert, C., 2000. Development of a PCR procedure for the detection of a herpes-like virus infecting oysters in France. J. Virol. Methods 88, 41-50.

Renault, T., Lipart, C., 1998. Diagnosis of herpes-like virus infections in oysters using molecular techniques. Presented at the Aquaculture and water : fish culture, shellfish culture and water usage.

Renault, T., Moreau, P., Faury, N., Pepin, J.-F., Segarra, A., Webb, S., 2012. Analysis of Clinical Ostreid Herpesvirus 1 (Malacoherpesviridae) Specimens by Sequencing Amplified Fragments from Three Virus Genome Areas. J. Virol. 86, 5942-5947.

Rossetto, C.C., Tarrant-Elorza, M., Verma, S., Purushothaman, P., Pari, G.S., 2013. Regulation of Viral and Cellular Gene Expression by Kaposi's Sarcoma-Associated Herpesvirus Polyadenylated Nuclear RNA. J. Virol. 87, 5540-5553.

Rubins, K.H., Hensley, L.E., Bell, G.W., Wang, C., Lefkowitz, E.J., Brown, P.O., Relman, D.A., 2008. Comparative Analysis of Viral Gene Expression Programs during Poxvirus Infection: A Transcriptional Map of the Vaccinia and Monkeypox Genomes. PLoS ONE 3, e2628.

Sauvage, C., Pépin, J.F. o., Lapègue, S., Boudry, P., Renault, T., 2009. Ostreid herpes virus 1 infection in families of the Pacific oyster, Crassostrea gigas, during a summer mortality outbreak: Differences in viral DNA detection and quantification using real-time PCR. Virus Res. 142, 181-187.

Schikorski, D., Renault, T., Saulnier, D., Faury, N., Moreau, P., Pépin, J.-F., 2011. Experimental infection of Pacific oyster Crassostrea gigas spat by ostreid herpesvirus 1: demonstration of oyster spat susceptibility. Vet. Res. 42, 27.

Segarra, A., Pépin, J.F., Arzul, I., Morga, B., Faury, N., Renault, T., 2010. Detection and description of a particular Ostreid herpesvirus 1 genotype associated with massive mortality outbreaks of Pacific oysters, Crassostrea gigas, in France in 2008. Virus Res. 153, 92-99.

Siah, A., Dohoo, C., McKenna, P., Delaporte, M., Berthe, F.C.J., 2008. Selecting a set of housekeeping genes for quantitative real-time PCR in normal and tetraploid haemocytes of soft-shell clams, Mya arenaria. Fish Shellfish Immunol. 25, 202-207.

Smith, J.D., Harven, E. de, 1973. Herpes Simplex Virus and Human Cytomegalovirus Replication in WI38 Cells I. Sequence of Viral Replication. J. Virol. 12, 919-930.

Tombácz, D., Tóth, J., Petrovszki, P., Boldogkői, Z., 2009. Whole-genome analysis of pseudorabies virus gene expression by real-time quantitative RT-PCR assay. BMC Genomics 10, 491.

Untergasser, A., Cutcutache, I., Koressaar, T., Ye, J., Faircloth, B.C., Remm, M., Rozen, S.G., 2012. Primer3-new capabilities and interfaces. Nucleic Acids Res. 40, e115-e115. 
Vandesompele, J., De Preter, K., Pattyn, F., Poppe, B., Van Roy, N., De Paepe, A., Speleman, F., 2002. Accurate normalization of real-time quantitative RT-PCR data by geometric averaging of multiple internal control genes. Genome Biol. 3, research0034.1-research0034.11.

Wobbe, K.K., Digard, P., Staknis, D., Coen, D.M., 1993. Unusual regulation of expression of the herpes simplex virus DNA polymerase gene. J. Virol. 67, 5419-5425.

Yager, D.R., Coen, D.M., 1988. Analysis of the transcript of the herpes simplex virus DNA polymerase gene provides evidence that polymerase expression is inefficient at the level of translation. J. Virol. 62, 2007-2015. 


\section{Figure caption}

Figure 1: Distribution of OsHV-1 genes according 5 putative protein groups: Unknown proteins, Enzymes, Ring finger proteins, Membrane proteins and Apoptosis inhibitors. Colors represent the OsHV-1 gene percentage, black and black shades denote 39 ORFs selected in this study and all ORFs of OsHV-1 respectively. These groups were described previously by Davison et al., 2005.

Figure 2: Percent cumulative mortality of Crassostrea gigas spat after injection challenge with OsHV-1. Bars represent SD of experimental infections $(n=3)$.

Figure 3: Virus DNA detection by real time quantitative PCR in oyster spat after intramuscular injection with OsHV-1. (Error bars represent SD, $n=9$ individuals at each collection time).

Figure 4: Heatmap illustrating 39 viral gene transcripts at 2 h, 4 h, 18 h, 26 h and 42 h by real time PCR. Colors represent the infected individual percentage, green and red denote no and all individuals positive respectively ( $n=9$ individuals analysed at each collection time).

Figure 5: Histogram of detection mRNA viral in 1/CT for all infected samples for ORFs belonging apoptosis inhibitors family A: ORF 42, B: ORF 87, C: ORF 99 and D: ORF 106) in Crassostrea gigas during experiment trial. Bars represent SD ( $n=2)$. ( $n=9$ individuals analysed at each collection time). 
Figure 6: Relative expression of the 8 viral gene transcripts (normalized to EF) in Crassostrea gigas mantle after infection with OsHV-1 using time $2 \mathrm{~h}$ pi as calibrator. Values are means of three replicates and bars represent SE $(n=9)$. * Mann Whitney test $(p<0.05)$. 
- ORFs selected $\approx$ All ORFs

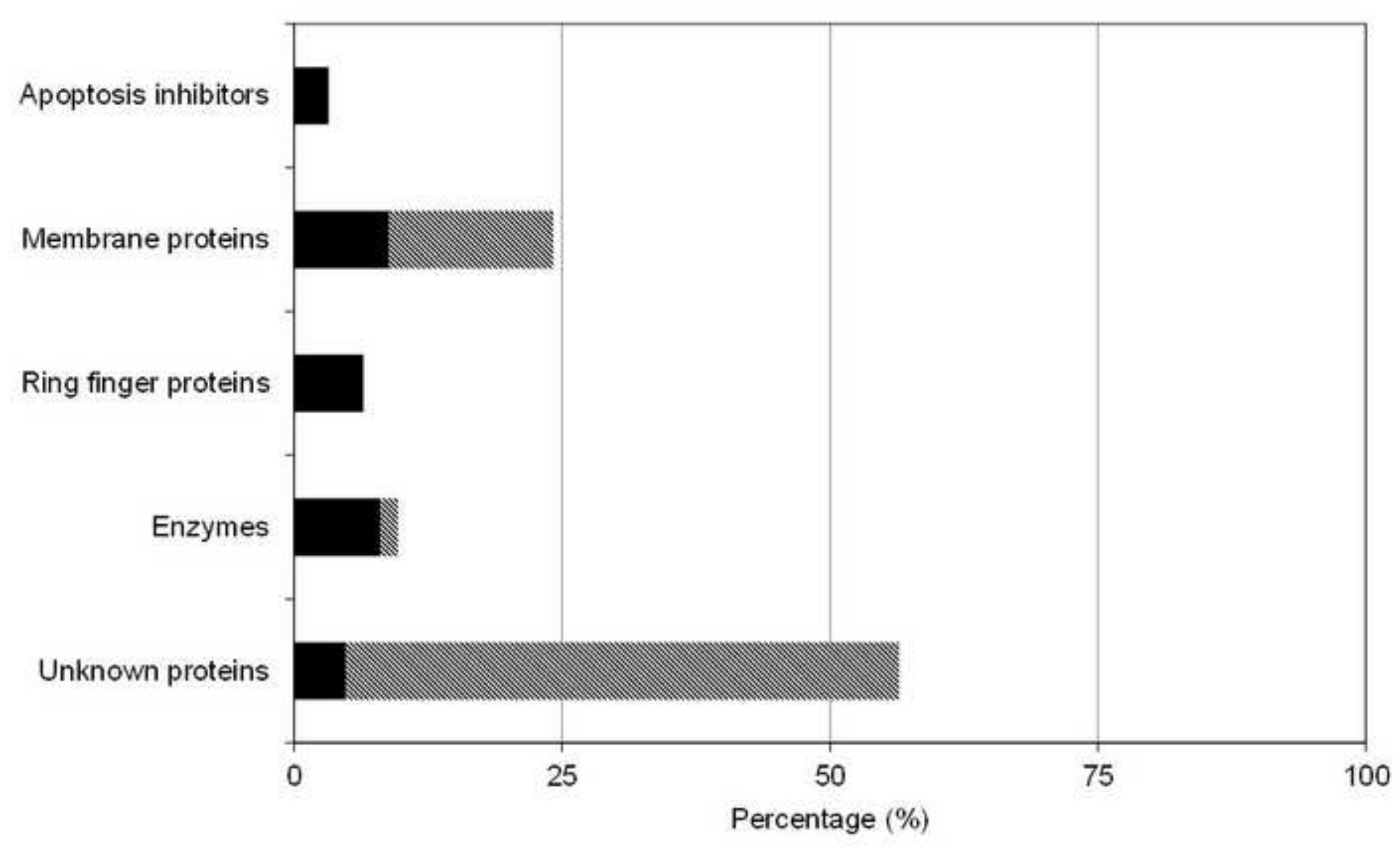



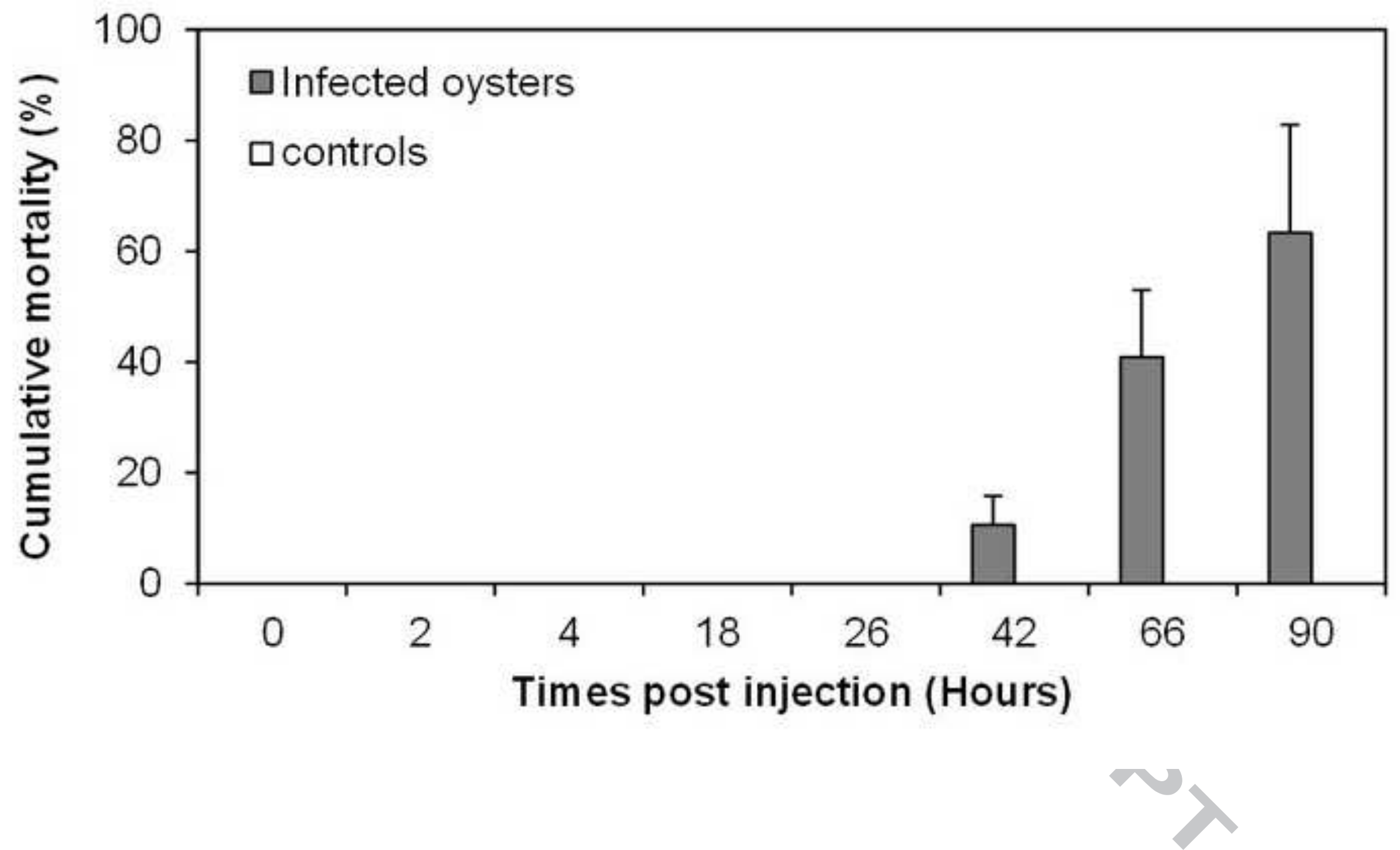


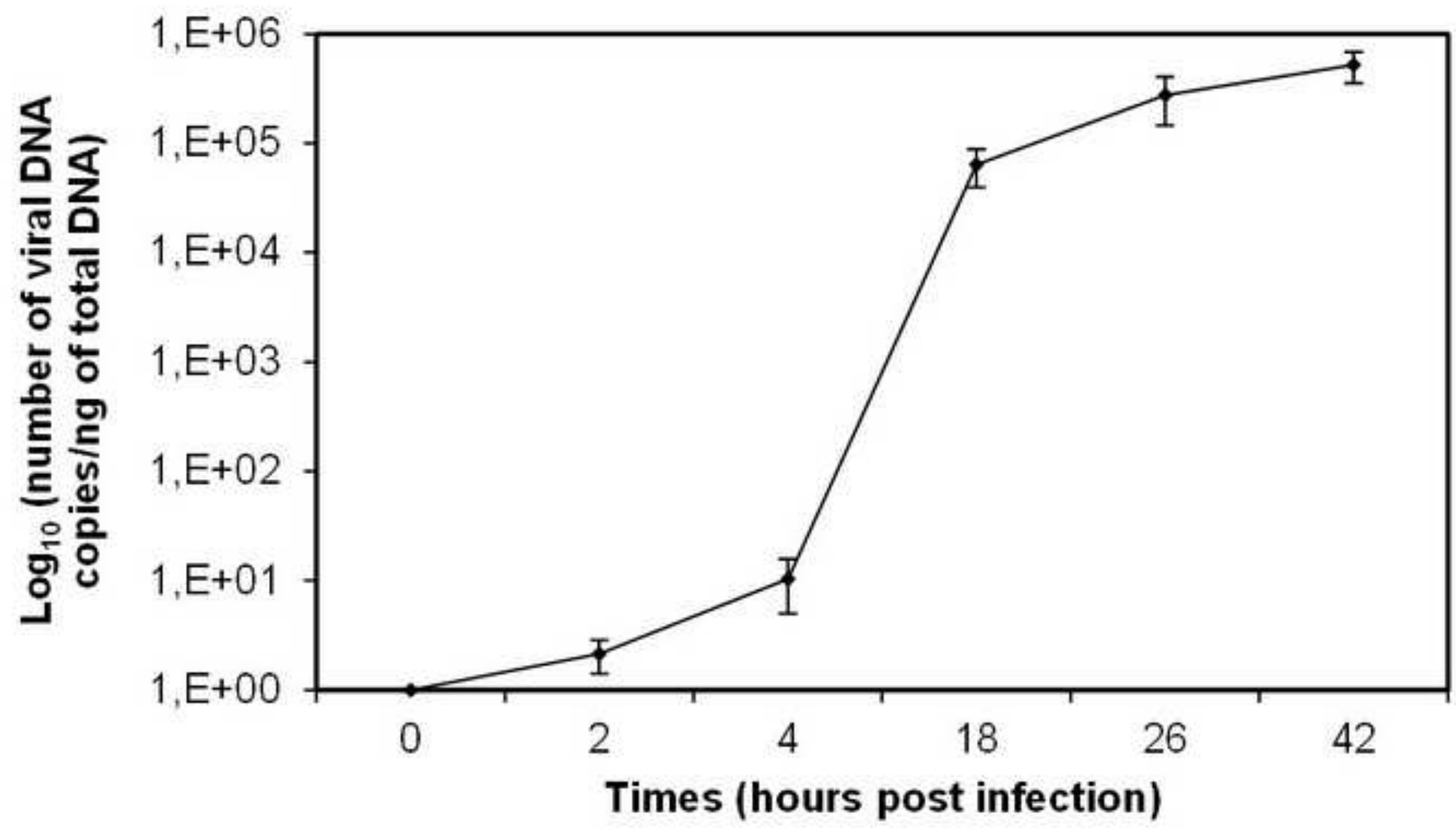




\section{ACCEPTED MANUSCRIPT}

$2 \mathrm{hpi} \quad 4 \mathrm{hpi} \quad 18 \mathrm{hpi} \quad 26 \mathrm{hpi} \quad 42 \mathrm{hpi}$
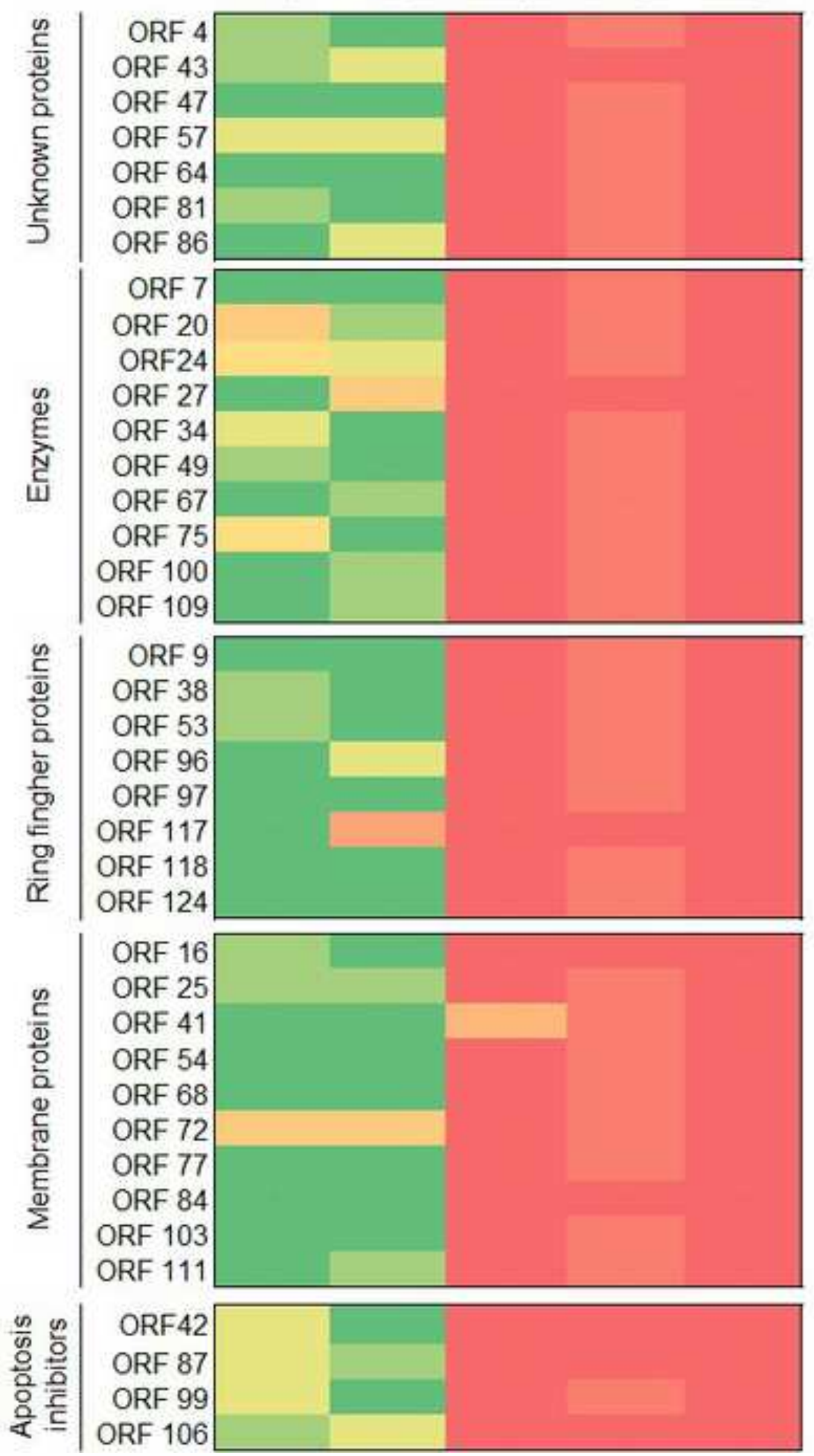

$0 \%$

$10-25 \%$ $26-40 \%$ $41-55 \%$ $56-70 \%$ $71-85 \%$ $86-100 \%$ 
A

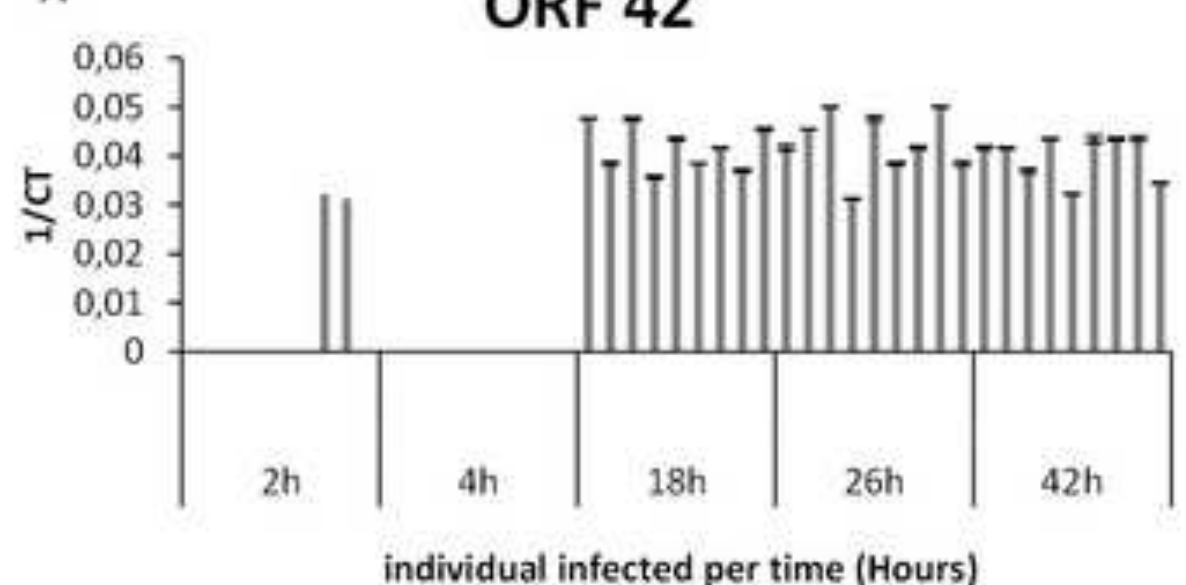

C

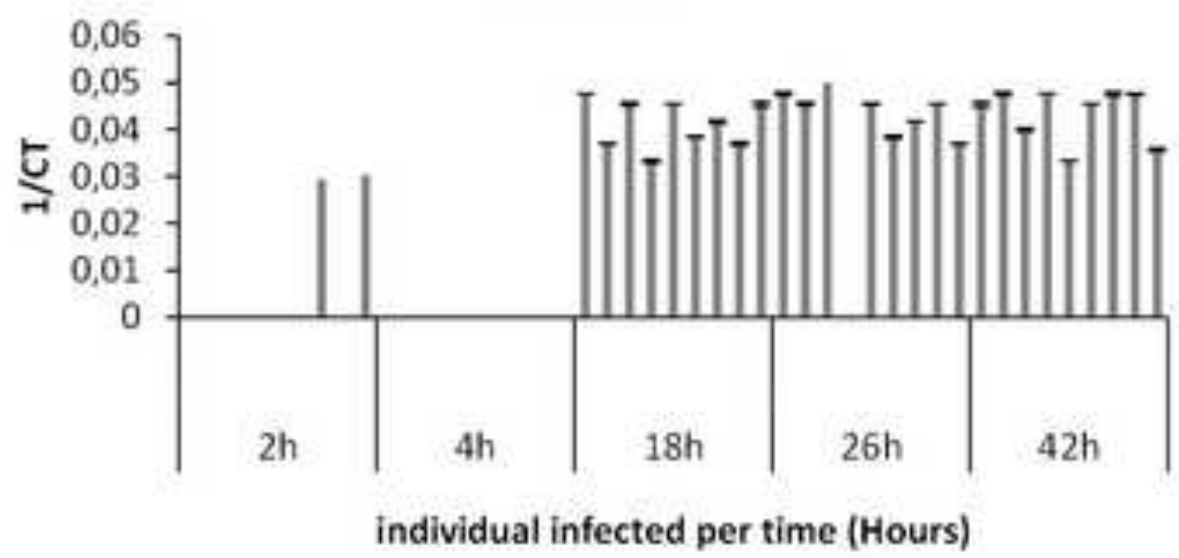

B

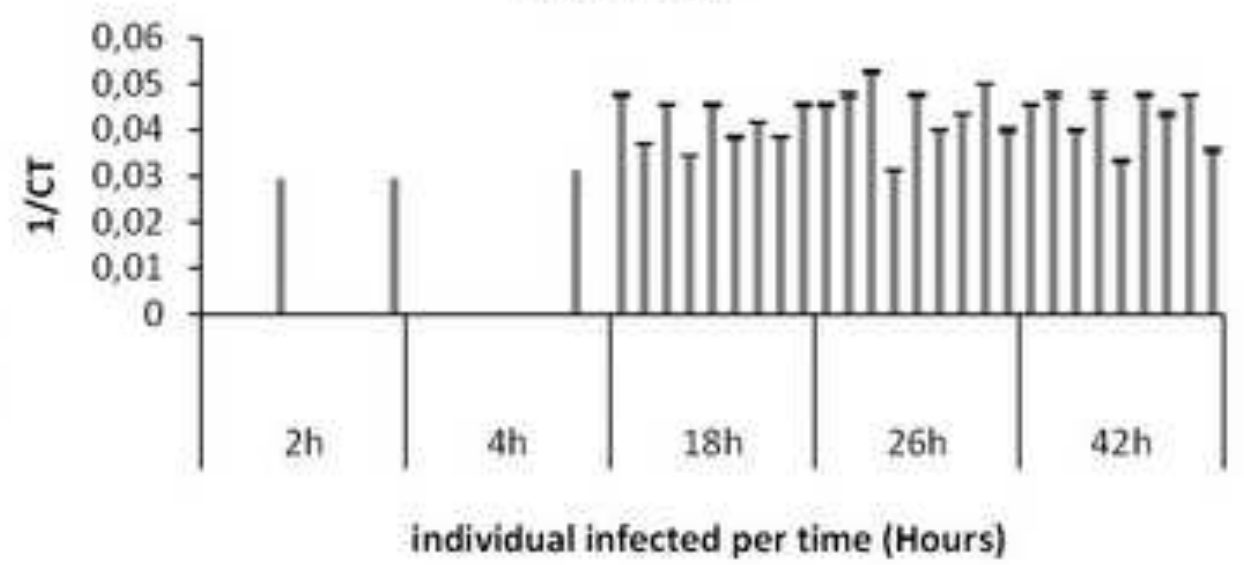

D

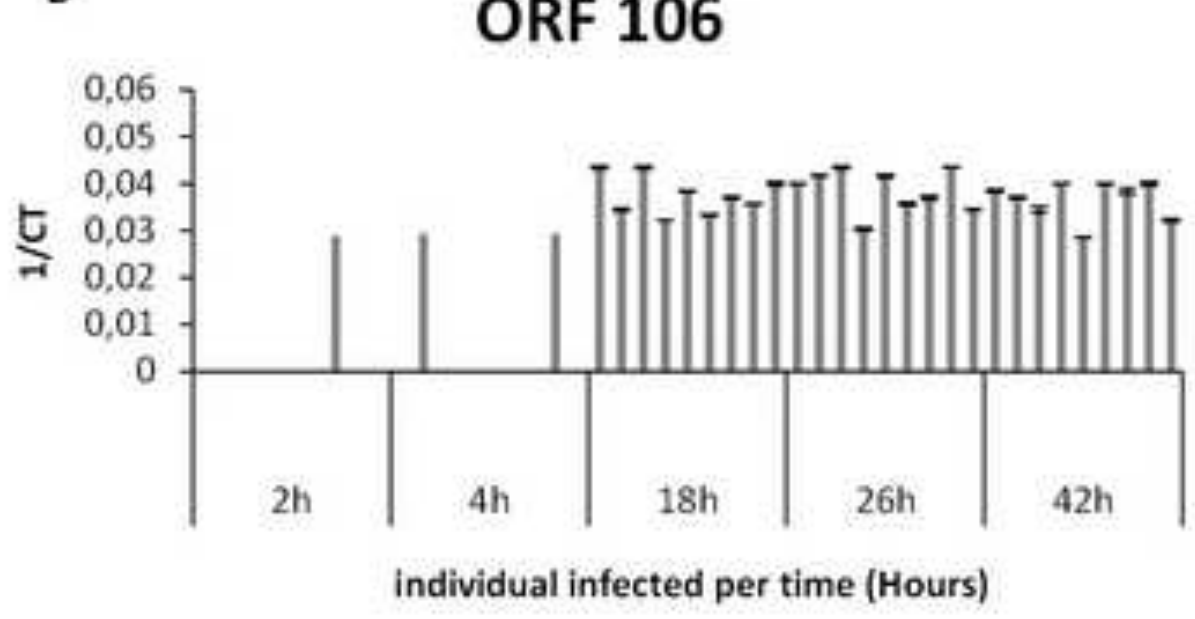




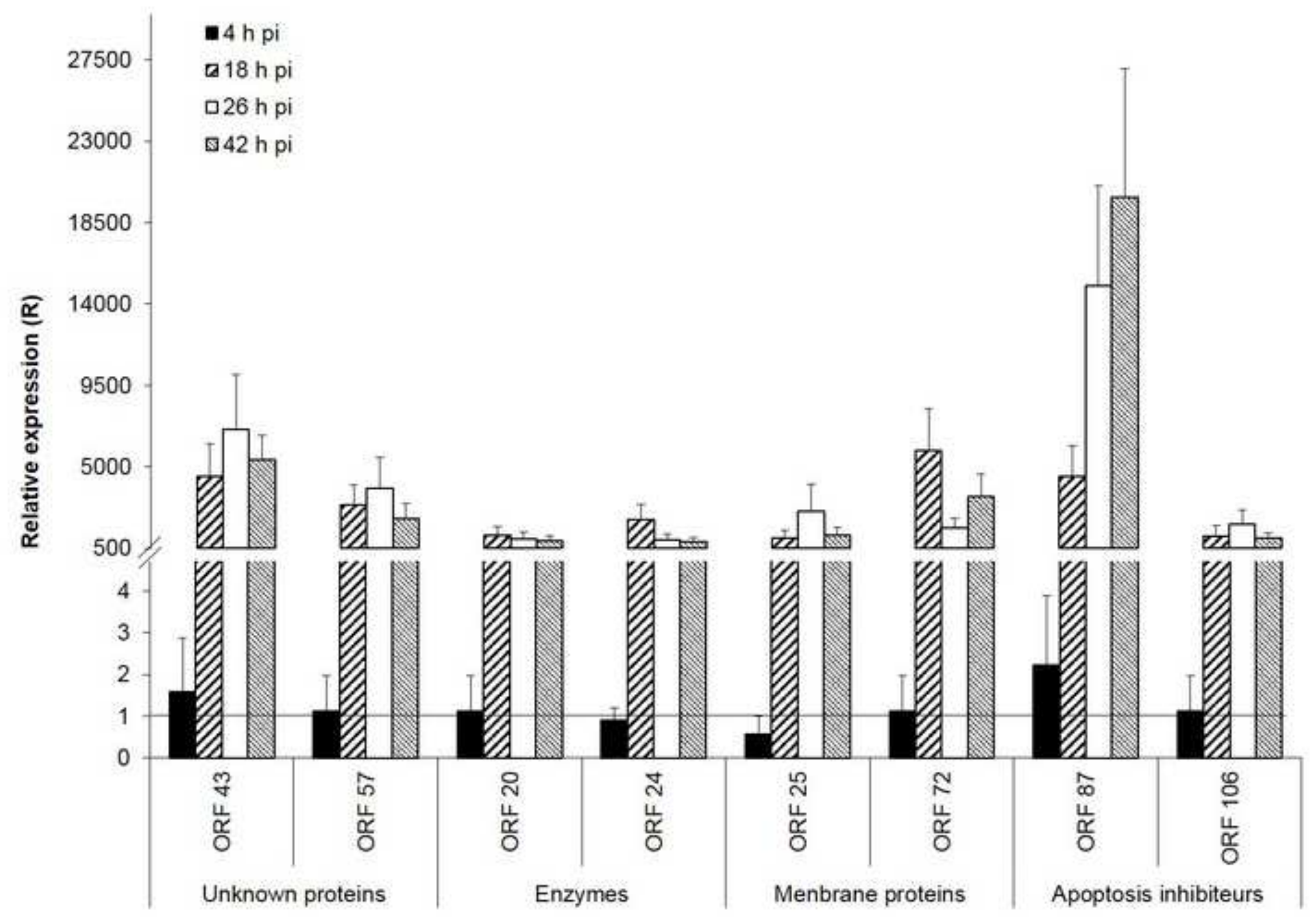


Table 1: Candidate genes housekeeping selected

\begin{tabular}{|c|c|c|c|c|c|c|}
\hline Actin & FJ669295 & $\begin{array}{l}\text { Cytoskeleton } \\
\text { structure protein }\end{array}$ & CACCAACTGGGATGACATGG & AGGGACAGTACGGCCTGGAT & 198 & 97.5 \\
\hline $\begin{array}{l}\text { Elongation factor 1-alpha } \\
\text { (EF) }\end{array}$ & AB122066 & $\begin{array}{l}\text { Translation } \\
\text { eukaryotic factor }\end{array}$ & AGTCACCAAGGCTGCACAGAAAG & TCCGACGTATTTCTTTGCGATGT & 200 & 98.8 \\
\hline Ribosomal protein (L5) & AJ563456 & Ribosome subunit & CCCATGAGCTGCCTCGATAC & GCACCTGAATGCACCTGGTT & 194 & 97 \\
\hline
\end{tabular}


Table 2: 39 Open Reading Fragments (ORFs) selected among 124 ORFs of OsHV-1.

\begin{tabular}{|c|c|c|c|c|c|}
\hline ORFs & Forward & Reverse & \begin{tabular}{|l|}
$\begin{array}{l}\text { Efficiency } \\
(\%)\end{array}$ \\
\end{tabular} & $\begin{array}{l}\text { Amplicon } \\
\text { (bp) }\end{array}$ & Protein \\
\hline ORF4 & tacaccggcctctttcagga & cgaattgttcactgcccaca & 96.1 & 217 & Unknown protein \\
\hline ORF7 & cgatagcgagggagacgatg & ccgtgtgttccattctgcaa & 100.8 & 198 & Primase(Enzyme) \\
\hline ORF9 & ccatcctcgttgggggtaat & cgtggcatgtgagcagagag & 98.9 & 189 & Ring finger protein \\
\hline ORF16 & tccaaacccagacccagctt & ccaaagagcaggccagggta & 102.4 & 148 & Membrane protein \\
\hline ORF20 & ctggctgttctgccatttcc & agacagcggcaaggtgatgt & 97.8 & 213 & $\begin{array}{l}\begin{array}{l}\text { Ribonucleotide } \\
\text { small subunit }\end{array} \\
\end{array}$ \\
\hline ORF24 & ccgccaaatgctctctcttc & tggaattgagggagccatga & 98.6 & 200 & Primase (Enzyme) \\
\hline ORF25 & ctcgccaaaggtcgtatcca & ccacaagggtgaattccatgtt & 98.7 & 200 & Membrane protein \\
\hline ORF27 & accgeccatggtgctaattc & cctgcaaggccaagtatgga & 97 & 189 & dUTPase (Enzyme) \\
\hline ORF34 & cttggacaaatgcatcccaaa & tggcacccacattcaaggtt & 100.7 & 183 & dUTPase (Enzyme) \\
\hline ORF38 & ttttgccatcgctcttcgtc & tgccctgtttgcagagaacc & 101.5 & 164 & Ring finger protein \\
\hline ORF41 & aaccgtgtgtcccaccattc & accgcagtgcaactccaatc & 102 & 183 & Membrane protein \\
\hline ORF42 & gcaggcataacaggtgagca & tgagaggcgtgacagggaat & 99.9 & 205 & Apoptosis inhibitor \\
\hline ORF43 & $\begin{array}{l}\text { tgaggataccagacccagacaa } \\
\text { gt }\end{array}$ & tcccaacctcttgcatcacc & 98.8 & 199 & Unknown protein \\
\hline ORF47 & gcgccaaaatggtagtggaa & tccttggcaggtcctgtgat & 98.6 & 202 & Unknown protein \\
\hline ORF49 & acccaaagtcggtggggtaa & cggagatttgcggtgtacca & 102.1 & 191 & Helicase (Enzyme) \\
\hline ORF53 & ccgaaaaaccagggactgga & tgggcgggaagtagatcgtt & 98.5 & 197 & Ring finger protein \\
\hline ORF54 & taaccatgggcaccgaagac & acatctcgccgctttgtcac & 95 & 193 & Membrane protein \\
\hline ORF57 & ttaccagcaccgagcaggat & tcgccgcttttatccaacac & 99.2 & 150 & Unknown protein \\
\hline ORF64 & gtacccaatgtggcagtgacaa & tttgatacggagacggggaag & 102 & 200 & Unknown protein \\
\hline ORF67 & gatgacggcattggtgaggt & cctgtgttgcggcttggtta & 98.5 & 195 & Helicase (Enzyme) \\
\hline ORF68 & ttggtaccggccattgacat & ggaaccgagtttgccacctt & 102.7 & 185 & Membrane protein \\
\hline ORF72 & acctccccgtcaatggtatga & tccaccacacccctacaatca & 94.7 & 180 & Membrane protein \\
\hline ORF75 & atgatctgcgccactctggt & tgtgcctgaaggatgtgcaa & 100 & 186 & dUTPase (Enzyme) \\
\hline ORF77 & cctgcattggcagtcggtat & tgcctgtgtggatgtcgaag & 103.2 & 189 & Membrane protein \\
\hline ORF81 & tggcacagtacacagcaccag & agaccccgccaaacgtctat & 95.7 & 182 & Unknown protein \\
\hline ORF84 & catctgtgctgtcatcgtcca & tgtacacctcggtgcaggtttt & 97.6 & 186 & Membrane protein \\
\hline ORF86 & tgaaaccagacatggacacacc & ccccgcagttatagcccaat & 98.0 & 185 & Unknown protein \\
\hline ORF87 & cacagacgacatttccccaaa & aaagctcgttcccacattggt & 98.7 & 196 & Apoptosis inhibitor \\
\hline ORF96 & caccataccggtggtgtcct & tgttgcgagtcatgctctgg & 100.9 & 180 & Ring finger protein \\
\hline ORF97 & acatcttcccccatgccatac & acgcatgttccagccatacc & 103.6 & 196 & Ring finger protein \\
\hline ORF99 & ggtggaggtggctgttgaaa & ccgactgacaacccatggac & 96.3 & 200 & Apoptosis inhibitor \\
\hline $\begin{array}{l}\text { ORF10 } \\
0\end{array}$ & accaggaccacgcctttgat & cccgcctttccataaattgg & 100.6 & 197 & DNA polymerase \\
\hline $\begin{array}{l}\text { ORF10 } \\
3\end{array}$ & gaggcattggcagcaagtgt & gctggcttctcgtcttggaat & 99.9 & 199 & Membrane protein \\
\hline $\begin{array}{l}\text { ORF10 } \\
6 \\
\end{array}$ & tctggcatccaacctccaaa & tcagcctatgacgaggcaatg & 100.8 & 200 & Putative apoptosis inhibitor \\
\hline $\begin{array}{l}\text { ORF10 } \\
9\end{array}$ & agtggccatgagtgccagat & ccacaacgcctgggtatgat & 102.3 & 165 & ATPase subunit (Enzyme) \\
\hline $\begin{array}{l}\text { ORF11 } \\
1\end{array}$ & cttccttggccaacgcctat & gcgttagacattcccgacca & 104 & 179 & Membrane protein \\
\hline $\begin{array}{l}\text { ORF11 } \\
7\end{array}$ & aatttcccgectctgtgctt & tgatgacggaagtggcaaca & 98 & 200 & Ring finger protein \\
\hline $\begin{array}{l}\text { ORF11 } \\
8\end{array}$ & ccggaaggtcgtcagggtta & caccttcgccacccgtatta & 95.7 & 183 & Ring finger protein \\
\hline $\begin{array}{l}\text { ORF12 } \\
4\end{array}$ & aagtccagcccacaacatgg & actggcgagacgtcattggt & 98 & 197 & Ring finger protein \\
\hline
\end{tabular}

